Journal of Teacher Education for Sustainability, vol. 14, no. 2, pp. 5-40, 2012

\title{
COURSE CURRICULAR DESIGN AND DEVELOPMENT OF THE M.SC. PROGRAMME IN THE FIELD OF ICT IN EDUCATION FOR SUSTAINABLE DEVELOPMENT
}

\author{
Vassilios Makrakis and Nelly Kostoulas-Makrakis \\ University of Crete, Greece
}

\begin{abstract}
This paper presents the design and development of a virtual learning enviroment (VLE) for a M.Sc. programme on information and communication technologies (ICTs) in education for sustainable development (ESD) driven by a learning paradigm that merges three theories of learning, namely: experiential learning, constructivist learning and transformative learning (ExConTra) funded by the European Commission. Learning activities were designed to offer the chance for students to interact asynchronously and synchronously, negotiate meaning and reflect on their learning and viewpoints through collaborative problem solving. The ExConTra learning process is also based on an interdisciplinary approach addressing the four pillars (environment, society, culture and economy) of sustainable development and makes use of an online course design methodology that uses four phases: needs analysis, curriculum design, development and formative evaluation. The VLE that encompasses both the curriculum programme and the online platform with its tools and online technologies merges ICTs with ESD in three ways: a) providing opportunities to target groups for reflective practice; b) using open source ICT tools and ESD-related learning objects available in the Web and c) using ICTs to develop interactive, interdisciplinary and cross-disciplinary ESD learning activities.
\end{abstract}

Key words: curriculum, information and communication technologies, online learning, education for sustainable development, Masters programme

\section{The challenges of ICTs in education for sustainable development}

The increasing rate of information and communication technologies (ICTs) development and their widespread implementation across all sectors of the economic and social life brings about radical changes in the way we work, think, learn and communicate. There is not, however, a universally accepted definition of ICTs due to the fact that concepts, methods and applications related to ICTs are constantly evolving and can be contextually interpreted and applied. A broad definition of ICTs is concerned with the distinction between 'old or traditional technologies' (radio, television, video, DVD, telephone, computers) and 'new or modern technologies' (video conferencing, e-mail, cellular telephones, weblogs, Web 2 and other 
social networking software). An 'old or traditional technology' might be a driving force for transformative change in its right context as a 'new or modern technology' could be a driving force in another context. No matter of technology development, educational systems, worldwide, face the challenge of preparing citizens who need to be equipped with the necessary skills and competencies to transform current unsustainable practices. In this context, teachers are increasingly called upon to switch from roles of being knowledge transmitters towards taking an active role as curriculum developers, knowledge constructors and transformative learning agents.

To prepare teachers to function within these roles, they have to receive an appropriate take off training and be prepared to on-the-job self-professional development. They should also be committed to play a leading role in promoting other teachers' professional development in their own schools, acting as resources and facilitators for service learning (Makrakis, 2006). Shifting from content-centred curricula to competence-based and life-skills curricula goes in parallel with shifts from teacher-centred teaching to student-centred learning enabled by ICTs. A competence is often associated with an individual's knowledge, skills and attributes in an effort to differentiate high performers from average performers and to develop their potential (Daley, 1991; Garvin, 2000). Drawing on the OECD DeSeCo work, Rychen and Salganik (2003) defined competence "as the ability to successfully meet complex demands in a particular context through the mobilisation of psychosocial prerequisites (including cognitive and non-cognitive aspects)" and as the "internal mental structures in the sense of abilities, dispositions or resources embedded in the individual" in interaction with a "specific real world task or demand" (p. 43). Another widespread classification refers to key or generic competences and disciplinary or specific competences.

In relation to sustainable development, there is extensive literature on what should be taught and learned in terms of knowledge, skills and values associated with sustainable development (Seitz \& Schreiber, 2005; De Haan, 2006; International Association of Universities [IAU], 2006; Makrakis, Kostoulas-Makrakis, \& Kanbar, 2012). The classical Brundland (World Commission on Environment and Development [WCED], 1997) definition for sustainable development allows current generations to satisfy basic needs without depriving future generations of the same right. In a panel review of 37 experts, sustainable development was consensually defined as making informed, contextual and conscious decisions driven by the principles of solidarity, justice, accountability, equity and transparency for the good of present and future generations, locally and globally and to act upon those decisions for advancing social, economic and environmental wellbeing (Makrakis, 2011b). Sustainable development is viewed as a dynamic, evolving and contested concept and practice for and within education, but, as Vare \& Scott (2007) suggest, "whether we view sustainable development as our greatest challenge or a subversive litany, every phase of our education system is being urged to declare its support for education for sustainable development" (p. 1). Education for sustainable development (ESD) or education for sustainability (EfS), used interchangeably, was also defined by the 37 panelists as the learning needed to maintain and improve our 
quality of life and the quality of life of generations to come. It is about equipping individuals, communities, groups, businesses and government to live and act sustainably, as well as giving them an understanding of the environmental, social and economic issues involved (Makrakis, 2011b). ESD/EfS represents a new vision of teaching and learning, a vision that helps people reconnect with nature, by addressing the complexity and interconnectedness of sustainability issues such as poverty, peace and international understanding, sustainable consumption and production, environmental degradation, climate change, water protection and health (United Nations Educational, Scientific and Cultural Organisation [UNESCO], 2005). This vision of education emphasises a holistic, interdisciplinary and cross-disciplinary approach to developing the competences needed for building a sustainable future. However, ESD, as a cross-curricula theme, is often marginalised in national curricula, which in turn reproduces and perpetuates academic divisions of knowledge that separate the natural and social sciences and the humanities and fails to acknowledge lay and tacit knowledge (Huckle, 2008).

An ESD student competence framework was developed, validated and implemented among 3.760 higher education students in 11 European and Middle East universities within the framework of a European Tempus initiative entitled "Reorient University Curricula to address Sustainability" (RUCAS) (Makrakis et al., 2012). The ESD student competence framework based on generic and disciplinary competences structured along five clusters was also used as a guide for curriculum design and development (Figure 1).

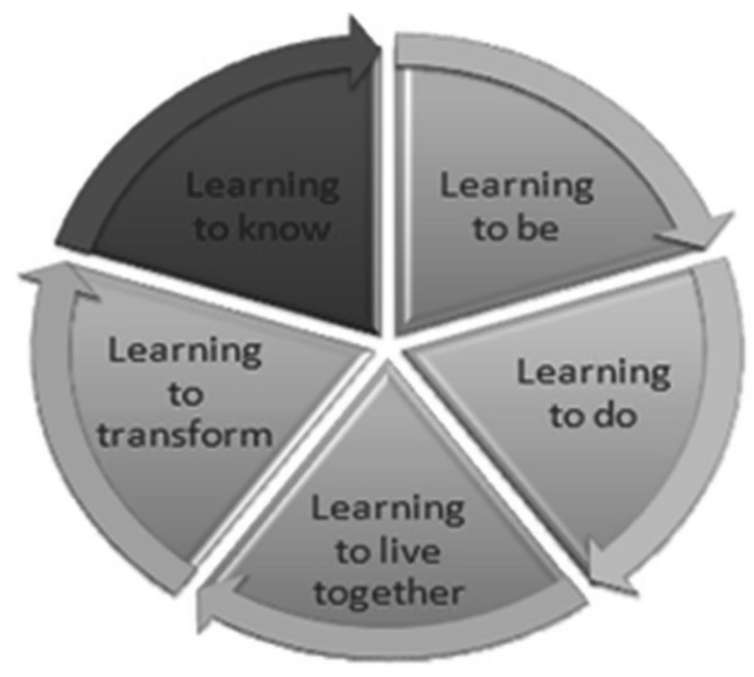

Figure 1. The five ESD clusters of competences

Learning and behavioural change are essential for achieving sustainable thinking and living (learning to live sustainably), which is inextricably connected to transformative perceptions of learning (Makrakis, 2012). Transformative learning focuses on learning-based change that involves 'learning to know', 'learning to do, 'learning to live together' and 'learning to be' (UN- 
ESCO, 1996). It is a shift of consciousness that alters: our way of being in the world (learning to be), our way for discovering others by discovering ourselves (learning to live together), our way of learning how to learn as well as acquiring, constructing, disseminating and managing knowledge (learning to know) and our way of putting knowledge into action (learning to do). It is above all learning that "transforms problematic frames of references - sets of fixed assumptions and expectations - to make them more inclusive, discriminating, open reflective and emotionally able to change" (Mezirow, 2003, pp. 57-58). Learning to transform oneself and society has been added by UNESCO as a fifth pillar of learning along with the previous four pillars advocated through the Delors report.

These five clusters of ESD competences applied in higher education supported by developments in ICTs and learning management systems, can open many more opportunities for course developers to introduce innovative teaching and learning methods enabling students to study in their own time and space. The internet and especially the World Wide Web is increasingly being used as a vehicle for open and flexible learning without geographical and time constraints, reaching greater numbers of socially, culturally and economically diverse students. Taking into consideration the unprecedented expansion of ICT-enabled distance education, it is a great challenge for promoting education for sustainability anywhere, anytime and any place.

The link between ICTs in education and sustainable development is being addressed by extensive debates and research which recognise the challenge ICTs bring to the reorientation of education towards learning to live sustainably (Makrakis, 2006, 2008, 2011a; Paas, 2008). ICTs can help learners explore concepts, engage in problem-based and authentic learning, enhance meta-cognitive skills and present information using multiple media (Makrakis, 2011b). All these are closely related to the goals, themes and learning objectives addressed by education for sustainability (Fien \& Tilbury, 1996; Huckle, 1996; Summers \& Kruger, 2003; UNESCO, 2005, 2010; Wals \& Corcoran, 2006). Indeed, three of the major forces shaping and driving the 21 st century education are: 1) the development and diffusion of Information and Communication Technologies (ICTs); 2) the increasing demand for new educational approaches and pedagogies that foster transformative and lifelong learning and 3) the reorientation of educational curricula to address sustainable development (Makrakis, 2011b).

Although the use of ICTs can offer exciting new possibilities to promote the changes called for developing knowledge and skills needed for a sustainable future along with changes in values, behaviour and lifestyles (UNESCO, 2003), simply merging ICTs to the transmissive teaching and learning practices will not work to achieve sustainability. Such a teaching model is principally based upon an objectivist approach that sees knowledge as something stable to be replicated in learners' minds, decontextualised from social reality and perceived as existing independently from learners' personal experiences. In decontextualised learning, school curricula and teaching methodology are mainly used in the context of instrumental rationality and technical interest in knowledge, which does little to develop human self-realisation and critical discourse (Makrakis \& Kostoulas-Makrakis, 2005). Instruction that is confined to a 
limited range of contexts leads also to inert knowledge in which facts and procedures remain isolated and are not activated in different problem-solving situations (Hasselbring \& Moore, 1996).

Previous research (Makrakis, 2006) shows that despite technological progress and infusion of ICTs in schools, the teachers' involvement with ICTs falls between prospective and occasional users. It is estimated that a 'take off' towards an innovative user stage will take place when 40 to 50 per cent of teachers will have reached the stage of engaged ICTs users. Teachers' ICTs uses seem to focus more on surface techno-centric skills associated with applications that do not integrate deep learning and reflective thinking. In general, teachers more frequently tend to use computers for low level uses, such as preparing student tests or demonstrating information for a lesson and less on more cognitive level uses related to creative thinking and problem solving. These results largely reflect the kind of training these teachers have received, as well as the ways in which new technologies are perceived and implemented in schools.

Summing up, the following are major challenges that need to be addressed when attempting to merge ICTs in ESD.

- Education sectors are lagging behind to capitalise on ICTs potential in promoting ESD.

- ICTs can empower and help to facilitate greater access to ESD learning by disadvantaged people, marginalised groups and communities. However, the 'digital divide' still remains a major challenge.

- ESD planning with new pedagogy is an essential part of building a whole school approach to ICT-enabled ESD.

- Dissemination and communication of information on innovative ICT-enabled ESD examples and practices may provide opportunities for embedding ESD in the curriculum supported by ICTs.

- A vision that facilitates an education model responsive to the development of ICTenabled ESD is often missing among education planners and policy makers.

While many nations around the world have embraced the need for education to achieve sustainability, only limited progress has been made so far. Some of the more prevalent challenges are: a lack of or inadequately trained professionals to provide inspired ESD; disciplinary boundaries between subject areas persist as well as lack of educational leadership to support transformative pedagogies to address sustainability. Our state-of-the-art reviews on Masters degree programmes in the field of ESD show that the great majority:

1. focus on the environmental pillar of sustainable development, neglecting the other three pillars (social, cultural and economic);

2. do not exploit the potential of ICTs in addressing sustainability issues, especially Web 2 technologies and use of open education resources (learning objects) available in the Web; and

3. employ techno-centric approaches, meaning that curriculum is developed by ex- 
perts without the end-users' inputs.

There is thus need of Masters degree programmes that are participatory, holistic, interdisciplinary and contextual, making use of ICTs both as learning pedagogies and means of delivering at a distance or through a blended mode. As a response to these challenges, seven European Universities, namely: University of Crete, Dublin City University, Daugavpils University, Frederick University, Open University of Cyprus, University of Graz and Uppsala University with considerable experiences in the fields of ICTs and ESD formed a Consortium to propose a project entitled "ICT-enabled Education for Sustainable Development". This project aims to develop a joint Masters degree (deployed on an advanced virtual platform) in ICTs in ESD which will be offered in English to target experienced practitioners in schools, community education, NGOs, government bodies and development agencies, who want to play a key role in moving forward the issue of ESD in their working environments. The specific objectives were to:

1. develop a joint Masters programme on ESD supported by ICTs consisting of interdisciplinary modules amounting to 120 ECTS. A diploma supplement will also be issued with the joint degree;

2. develop course modules addressing the environmental, social, cultural and economic pillars of sustainable development supported by social software tools and infused by open source learning objects;

3. develop a virtual learning platform for uploading course content, enrolment and maintenance of student records, academic profiles, scheduling of units, course monitoring, liaison etc. combining two open source platforms (Moodle and Mahara);

4. develop an online training toolkit addressed to university staff who want to infuse ESD into their teaching and courses and/or apply virtual tutoring modalities;

5. implement the training toolkit with 25 university staff from partner institutions to support the running of the joint Masters programme.

The place of ESD in higher education is not one of integration as a stand-alone subject, but rather one of innovation that will generate deeper changes in all practices and structures of higher education institutions. Addressing and promoting ESD in higher education institutions would require a new conception of the triangle ICTs, curriculum and pedagogy.

\section{Conceptions of ICTs, curriculum and ESD pedagogy}

It is often said that education plays a dual role. On the one hand, it reproduces certain aspects of current society and, on the other hand, it prepares students to transform oneself and society. Although these roles are not necessarily mutually exclusive, curricula in the past tended to reproduce an unsustainable culture rather than empower citizens to think critically and learn to transform oneself and society. This is largely due to the fact that many still equate a curriculum with a body of knowledge-content to be transmitted to students by applying the 
most effective teaching methods (curriculum as product). The product model of curriculum can be traced to the work of the writings of Tyler (1949, as cited in O’Neill, 2010) who greatly influenced curriculum development worldwide. In a product model, behavioural objectives are pre-specified in a way that can be objectively measured. This leads to a focus on the parts rather than the whole; overlooking learning that is occurring as a result of the peoples' interactions with their environments. Behavioural objectives that can be measured provide the foundations on which the curriculum as a product is built. The intended outcome of a learning experience is thus prescribed or pre-specified in advance. The idea of curriculum as a product has been contrasted to two other types: curriculum as process and curriculum as praxis (Grundy, 1987).

The curriculum as process is being considered more open-ended than the product curriculum. In a process model, instead of prescribed and measurable learning objectives, intentions or more flexibly formulated objectives mostly negotiated with learners are set. Curriculum as praxis is, in many respects, a development of the process model. However, while the process model is driven by general constructivist principles and places an emphasis on interpretation, judgment and meaning making, it does not make explicit statements about the interests it serves. Grundy (1987) argues that to understand the terminology of curriculum, it is important to pay attention to the theory of 'knowledge-constitutive interest' or 'actionconstitutive interest' developed by Habermas (1971). Habermas's distinction goes back to the classical Aristotelian contrast between techne and praxis. For Aristotle (2004), praxis is guided by a moral disposition to act truly and rightly (phronesis - practical wisdom); a concern to further human wellbeing and the good life. The Aristotelian conception of praxis, referring as poiesis, is about acting upon something that does not entail conceptions of empowerment and emancipation that praxis aims to. Technical interest is an interest to control, predict and manage the environment deeply-rooted on modes of inquiry, curriculum and pedagogy in the 'empirical-analytic' or positivist sciences. Practical interest rooted in the interpretive-hermeneutic sciences is an interest of mutual and self-understanding in the conduct of life driven by modes of action-orienting (inter)personal understanding. Finally, the emancipatory interest is an interest of critical self-reflection, leading to empowerment, praxis and emancipation that aim to free science from its positivist illusions. It may, for instance, be used in such a way that does not make continual reference to collective human wellbeing and to the emancipation of the human spirit (Grundy, 1987; Smith, 2000; Makrakis, 2012). In this approach, the curriculum itself develops through the dynamic interaction of experience, action and reflection. "That is, the curriculum is not simply a set of plans to be implemented, but rather is constituted through an active process in which planning, acting and evaluating are all reciprocally related and integrated into the process" (Grundy, 1987, p. 115).

When relating Grundy's curriculum typology and the three Habermasian knowledgeconstitutive interests to ICTs in education, several points may arise. First, the emergence of ICTs as learning technologies have coincided with a growing awareness and recognition of alternative theories for learning that go beyond pedagogies rooted in the empirical-analytic 
paradigm, driven by a technical interest. ICTs driven by constructivist learning theories have contributed to shifting curriculum as a product to curriculum as a process. Through ICTsenabled and enriched learning settings students take responsibility for their own learning instead of being consumers of a prescribed curriculum. Constructivist principles posit that learning is achieved by the active construction of knowledge supported by various perspectives and social interactions that play a critical role in the processes of learning and cognition. ICTs enable people to undertake education anywhere, anytime and any place and, in this way, fill various gaps and satisfy special needs, despite the fact that the so-called digital divide is still present. However, although ICTs give people the power to free themselves of routine works and be engaged with more cognitively demanded tasks, they cannot be seen as emancipatory tools unless an explicit statement about the interests ICTs serve is made. The praxis model of curriculum theory and practice applied to ICTs makes an explicit commitment to their true emancipatory potential. Thus, the concept of praxis is not simply using ICTs to freeing people from lower cognitive demanded works, but a commitment to use ICTs as enabling tools to turn people able to act as agents of change (Makrakis \& Kostoulas-Makrakis, 2012ab). This kind of agency enabled by ICTs can be seen in various levels and directions.

ICTs enable instructors to transform their teaching practices by facilitating studentstudent and student-teacher interactions and collaboration in meaningful or authentic learning settings. Transformative learning is a process whereby "we transform our takenfor-granted frames of reference to make them more inclusive, discriminating, open and reflective so that they may generate beliefs and opinions that will prove more true or justified to guide action" (Mezirow, 2000, p. 214). In other words, “Transformative learning involves experiencing a deep, structural shift in the basic premises of thought, feelings and actions. It is a shift of consciousness that dramatically and irreversibly alters our way of being in the world. Such a shift involves our understanding of ourselves and our self-locations; our relationships with other humans and with the natural world" (O'Sullivan, 2003, p. 327). Freire's (1993) emphasis on praxis action and reflection is pedagogically illuminated by Kolb's (1984) active learning cognition theory that gives due emphasis to experiential learning. Different online communication tools and learning environments enabled through Web 2.0 technologies offer the potential for new forms of experiential, constructivist and transformative modes of learning. Such learning "would develop sustainability literacy (their ability to read the symptoms and causes of unsustainable development and write more sustainable futures) whilst also contributing to political literacy and the development of identity" (Huckle, 2012, p. 139). This approach to the theory of curriculum, because it places meaning-making and thinking at its core and treats learners as subjects rather than objects, if coupled with the human agency perspective, can lead to curriculum constructions that facilitate learning to transform oneself and society. ICTs can be used to transform learning experiences but that this depends to a considerable extent on the way the curriculum is conceived and how it is enacted through the processes of teaching and learning. The focus on linear pedagogies and pre-specified curriculum goals may lead both educators and learners to overlook learning 
that is occurring as a result of their dynamic interactions enabled by ICTs. Learning and curriculum in this sense must not only be planned and structured by a participatory design approach, but also by the tasks and learning situations and the interaction with the social environment in which learning takes place. Thus, the conception of curriculum as context should be also added to the three previous curriculum conceptions, if the content of the knowledge produced and disseminated is sufficiently responsive to the problems and needs of the targeted populations and their societies. ICTs can thus be a context for ESD as well as ESD can be a context for ICTs.

- ESD themes integrated into the school curricula could provide a worthwhile context for ICTs in education. For instance, social, economic and environmental issues can provide meaningful and challenging contexts for developing a wide range of ICT skills.

- ESD methods are conducive with constructivist and transformative learning theories, which can provide a context and rationale for using ICT-based learning tools such as concept mapping, modelling, social networking.

- When considering areas such as cultural diversity and intercultural understanding, health, HIV/AIDS, governance, natural resources, climate change, rural development, sustainable urbanisation, poverty alleviation, corporate responsibility and accountability, there is potential to assess the impact of ICTs in these key sustainable development areas.

- However, the so-called digital divide, especially for women and other disadvantaged groups, is still a problem that challenges educators and policy makers.

The question which arises is: What curriculum type to choose for developing the M.Sc. programme? Our standpoint is that in practice, there is a continuum between the three curriculum types, despite their fundamental differences in ontological, epistemological, methodological and axiological level. The complementarity of the three approaches, in terms of their methodological dimension, does not degrade the important differences and the entailed consequences for the design and the use of curricula enabled by ICT tools. In other words, the questions: What to teach? What to learn? and How to learn? should not be put in practice in an early stage of the curricular development process, which would exclude at a starting point the targeted students and the main actors to be involved in its implementation. The curriculum "is not simply a set of plans to be implemented, but rather is constituted through an active process in which planning, acting and evaluating are all reciprocally related and integrated into the process" (Grundy, 1987, p. 115). Our major assumptions on ICTs, curriculum and ESD pedagogy that provided guidance to the process of curriculum design were:

- We do not see curriculum as a simplification of a linear process that dictates what is to be learned and how it will be learned without taking into consideration those concerned.

- The environment or context in which learning will take place is a critical compo- 
nent of the course curriculum design process.

- Emphasis should be placed on reflective problem-based learning enabled through tools and services that facilitate 'social networking' for virtual collaboration and virtual peer mentoring amongst learners and e-tutors.

- Knowledge is seen as a process of making meaning through interaction. In this sense, the curriculum is viewed as a process shaped by the interactions of those involved, whose needs and interests matters.

- Putting strong emphasis on transformative pedagogies and a commitment to promote the values and principles of education for sustainability is a condition for building a sustainable society.

- While we are committed to a critical and transformative learning paradigm, we assume the complementarity of the opposite paradigms, in cases that their contribution adds value to our philosophical and methodological commitments.

- Course curriculum design integrates actions for: embedding critical literacies and learning in complex, realistic and relevant environments; applying social negotiation as an integral part of learning; integrating multiple perspectives and the use of multiple modes of representation; encouraging ownership in learning; providing adequate time for problem-based and inquiry-based learning.

\section{The underpinning learning philosophy for designing the M.Sc. programme}

Teaching and learning that underpins the design of a course programme is not free of values. Especially, to design teaching and learning that aims to turn learners able to transform themselves and society, it implies that designers must not only adhere to certain values, but also articulate them and reflect on them and the choices for actions that they necessitate. After presenting our major theoretical standpoints with respect to curriculum theory, it is necessary now to expose the learning theory that, explicitly or implicitly, has been guiding us in the design and development of the M.Sc. programme on ICTs in education for sustainable development.

Despite variations of learning theories within specific learning paradigms, there are three basic categories of learning theory that are driving instructional and learning design models: 1) instructive; 2) constructive and 3) transformative. The first is based on behaviourism and partly on cognitivism (labelled also as objectivism); the second on interpretivism and partly on cognitivism and the third on critical constructivism and critical pedagogy. The main goal of instruction for behaviourism and congnitivism is to prescribe learning goals and observable/measurable outcomes and to transfer or bank knowledge to students, taking thus a teacher-centred and mechanistic/deterministic approach to human learning. Freire (1993) refers to this as a 'banking model' of education and criticises it for its view of learners as objects of learning. However, the cognitivists stress the acquisition of knowledge and internal mental processes and structures, while behaviourists focus on external environmental conditions through the organisation of stimuli-response-reinforcement association to modify behaviour 
in the desired learning direction. In other words, cognitivism defines learning more broadly to include the role of mind as a schematic network and memory in storing and retrieving knowledge as well as a change in thinking, beliefs, attitudes and values, while behaviourism defines learning more narrowly to include mastering of prescribed learning outcomes.

In contrast to instructive learning, constructive learning environments are characterised as being open and flexible, learner-centred, less prescriptive. The teacher is viewed as facilitator/mentor and learners are actively involved in making meaning and constructing knowledge. In other words, learning is deemed as social (negotiated) active, contextual (real-world based), authentic and meaningful. According to Cey (2001), authentic learning occurs when instruction is designed to facilitate, simulate and recreate real-life complexities and occurrences. Squires (1999) refers to 'cognitive authenticity' through the articulation of ideas, experimentation and engagement in complex environments as well as 'contextual authenticity' through the relation of tasks to the real world. Meaningful learning occurs when students develop effective ways to resolve problematic situations that require knowledge to be constructed by the learner, not transmitted from the teacher to the student. According to Jonassen, Peck and Wilson (1999), meaningful learning is:

- active (manipulative): learners interact with the environment, manipulate the objects within it and observe the effects of their manipulations;

- constructive and reflective: learners reflect on their activities and observations and interpret them to create a meaningful learning experience;

- intentional: to experience meaningful learning, learners must be able to articulate their own learning goals and monitor their own progress;

- $\quad$ authentic (complex and contextual): learning is meaningful, better understood and more likely to transfer to new situations when it occurs by engaging with real-life, complex problems;

- cooperative (collaborative and conversational): meaningful learning requires conversations and group experiences.

Constructivism gives less emphasis to the sequence of instruction and more emphasis on the design of the learning environment and constructing knowledge through social negotiation and cognitive conflict as the stimulus for learning (Jonassen, 1994; Savery \& Duffy, 1996). Philosophically, the strengths of constructivism lie in its emphasis on learning as a process of individual understanding and meaning making rather than the memorisation of facts (Jonassen \& Reeves, 1996). In particular, the social constructivists based on Vygotsy argue that the structured and linear process offered by the objectivistic conceptions of learning is problematic (Kanuka \& Anderson, 1999). As learners have different social experiences and levels of understanding, it implies that there is no one reality as objectivists assume, but there exist multiple realities of how the world works and multiple ways of interpreting these realities (Jonassen, 1991). Thus, constructing is a sociolinguistic process where there is gradual advancement of understandings built upon previous knowledge resulting in multiple dimensions of the truth (Spiro, Feltovich, Jacobson, \& Coulson, 1992). 
Constructivist learning environments can be enabled by an abundance of ICT tools that can enhance communication, access to real-world examples, reflective thinking, multiple perspectives, modelling or problem solving by experts in a situated context domain. Situated learning as introduced by Wenger and Lave (1991) states the importance of knowledge acquisition in a socio-cultural context and that the integration in communities of practice enabled by ICTs may lead to active construction and reflection about knowledge. The idea of situated learning is also closely related to the ideas of 'blended learning' and 'learning on demand', especially in games targeting adults at their workplace (Oppermann \& Specht, 2006). This notion of learning on demand coined also as embedded learning (Straub, 2005, as cited in Schmidt, 2008), work-integrated learning (Lindstaedt, 2006, as cited in Schmidt, 2008) or context-aware workplace learning support (Schmidt \& Braun, 2006) opens a space for contextualising learning in the workplace, especially through the support of ICTs. What we actually need is learning on demand, embedded into work processes, responding to both requirements from the work situation and from employee interests, a form of learning crossing boundaries of e-learning, knowledge management and performance support (Schmidt, 2005). The contextualisation of the learning on demand can not only be seen from the point of view of an actual problem or learning situation but also in a longer lasting process of learning activities that are integrated (ibid.).

Marsick \& Mezirow (2002) and Mezirow (2000) extend the assumptions made by constructivists by incorporating the transformative and political dimension in their views of teaching and learning. The questions: What should be learned? or, to put it alternatively, What is the most valuable knowledge? How should it be produced? and What teaching and learning methods would it be used by? fall in the sphere of politics and ethics in education. Transformative learning originated as an adult education based theory that suggests ways in which adults make meaning of their personal experiences. Mezirow (2000) defines transformative learning as a process by which our taken-for-granted frames of references are transformed by making them more inclusive, discriminating, open, emotionally capable of change. Tilbury, Podger and Reid (2004) are stressing the 'conceptual congruence' between ESD and transformative learning as the goals and objectives of both apparently coincide. The congruence between the aims of ESD and transformative education has also been highlighted by Walls and Corcoran (2006) and Svanstrom, Lozano-Garcia and Rowe (2008). Mezirow (2000) argued that transformations often follow some variation of the following phases:

- a disorienting dilemma;

- a self examination with feelings of guilt or shame;

- a critical assessment of epistemic, sociocultural or psychic assumptions;

- recognition that one's discontent and the process of transformation are shared and that others have negotiated a similar change;

- $\quad$ exploration of options for new roles, relationships and actions;

- planning a course of action;

- $\quad$ acquisition of knowledge and skills for implementing one's plan; 
- $\quad$ provisional trying of new roles;

- building of competence and self-confidence in new roles and relationships.

Thus, transformative learning is, in a sense, the deconstruction of learners' prior assumptions or frames of reference (points of view, habits of mind, worldviews) through critical reflection (praxis) as well as the reconstruction of their assumptions through meaning making. For Tilbury et al. (2004), it is the emphasis on processes of critical and personal reflection, the focus on change and shifting of values and behaviours that are common features of both ESD and transformative learning. The emancipatory domain inherent in the transformative paradigm is the place where learners can free themselves from any restrictions and actively question their assumptions through critical reflection and praxis. Elliott (2010) found that the key transformative shifts in ESD learning involve learning to value sustainable development and learning how to make it happen. McLaren (1994) defined praxis as "informed actions" and stated that "actions and knowledge must be directed at eliminating pain, oppression, and inequality, and at promoting justice and freedom" (p. 190). Darder, Baltodano and Torres (2003) considered praxis as "all human activity... understood as emerging from an ongoing interaction of reflection, dialogue and action" (p. 15). Cranton (1994) concisely listed three types of reflection that involves movement toward the emancipatory domain: content, process and premise reflection. Content reflection is an examination of the content or description of a problem; process reflection involves checking on the problem; premise reflection happens when the problem itself is questioned.

Critical pedagogues perceive teachers as transformative intellectuals who are involved in developing a discourse that unites the language of critique with the language of possibility (Giroux, 1988). Teachers functioning as transformative intellectuals are giving students an active voice, making the political more pedagogical and the latter more political (Giroux, n.d.). McLaren (1994) argued that "teachers must understand the role that schooling plays in joining knowledge and power, in order to use that role for the development of critical and active citizens" (p. 168). Huckle (2012) suggests that teachers should be introduced to critical social theory that seeks to explain the role of Web 2 technologies in the recent wave of capitalist development that precipitated economic and ecological crisis and their potential to bring about more sustainable alternatives. He argues that such alternatives will be based on more radical and deliberative forms of democracy and citizenship enabled by the new technologies. In this context, Huckle (2012) assumes that teacher education for sustainability should equip teachers to explore these through appropriate forms of citizenship education and model them in their classrooms via new forms of critical pedagogy. Besides creating a learning environment that encourages students' active participation in the learning process, critical pedagogy extends participation to the co-construction of curriculum. In this way, it is believed that learners' needs, interests and learning styles are meaningfully integrated into what they learn and how they learn it. Through this process and practice, the learning environment adopts distributed or shared responsibilities between teacher and students, which may facilitate the process of negotiating the curriculum structure, content and assessing criteria. 
In trying to bring together the main principles of the constructivist and critical pedagogy theories, assuming that experiential learning is crossing the two (for instance, Kolb \& Kolb, 2005), we have conceptualised a construct abbreviated as ExConTra, that corresponds to Experiential learning, Constructivist learning and Transformative learning depicted in Figure 2 (Makrakis \& Kostoulas-Makrakis, 2012a).

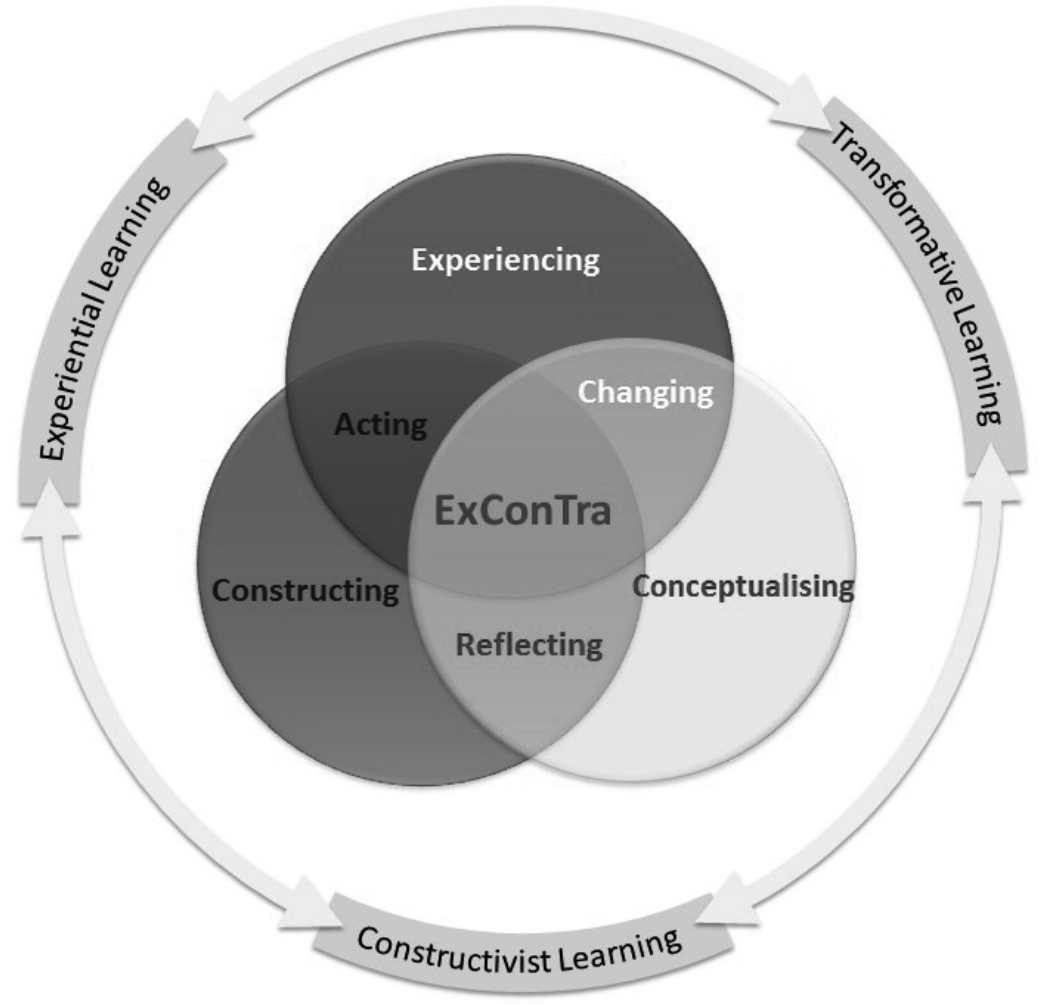

Figure 2. The ExConTra learning model

Beginning with experiencing, learners identify a realistic and authentic task associated with a sustainable development issue and start collecting the information needed for their analyses, using various inquiry-based methods. Through reflecting, self and/or social, as well as through further reading and observing, learners organise and examine the collected data for the new experience from a variety of perspectives in order to find and make meaning. For learners to make meaning, either individually and/or shared, they need to reflect on their own experiences, leading them to develop more abstract understandings of their experiences (conceptualising). Arriving at individual and shared meaning (constructing), learners need to get involved in a meaningful learning and shared inquiry enriched through continuous reflection, re-conceptualisation and active experimentation. Constructed knowledge and meaning is meaningful when it opens up 
opportunities for action. Merging knowledge and meaning with action (acting) leads to a change agency and active citizenship. Acting as change agents, learners are empowered to transforming experience through critical reflection and active experimentation. When critical reflection is transformed into an action it becomes praxis that turns learners able to transform oneself and society (transforming).

These processes can be enriched by ICTs as they provide many opportunities for experiential, constructivist and transformative learning experiences, especially by enabling learning to be related to context and to practice. ICTs provide an array of powerful tools that may transform teaching and learning processes and turn learners able to take greater responsibility for their own learning and constructing their own knowledge. The development of social media and networks has also led to a blurring between the public and private spheres, which has provided opportunities for communication, but also has brought dangers to some when private information has become public or when the virtual world has enabled people to practise deceit and deception (Wade, 2012). ICTs create the potential for new modes of dialogic communication, empowerment and critical reflection that could enhance social learning for sustainability. Wals (2007) states that sustainability addressed as a social learning process is rooted in the life-worlds of people and the encounters they have with each other. Social learning theory is gaining prominence as a critical theory and research approach to studying ecosystems management, climate change and education for sustainability (Wals \& Heymann, 2004; Glasser, 2007; Wals, 2007). Online collaborative discussions are increasingly notable for their role in social construction of knowledge by providing shared virtual workspaces for brainstorming, debating, discussing or reflecting on issues of learning among learners, instructors or even invited guest speakers (Lim, 2007). Using social networking and video-conferencing programmes in conjunction with online courses offered through learning management systems such as Moodle is a means to expand student-student and student-tutor collaborative learning. Students' social learning for sustainability can be also enhanced through asynchronous discussion, which provides students the opportunity to post ideas and thoughts, read and comment other students' ideas. Both synchronous and asynchronous online discussions can foster critical reflection and create a foundation for transformative learning.

New approaches to content distribution, particularly the OpenCourseWare (OCW) and open educational resource (OER) movements, promise to make a vast array of content open to instructors and students to reuse, revise, remix and redistribute (Bush \& Mott, 2009). OCW and OER can be labelled as learning objects (LOs) indexed and catalogued in digital repositories. The LOs are either simple (for instance, pictures, documents, video, audio clips) or complex (for instance, learning management systems, portals, chat software, blogs, wikis, discussion boards) and can be easily transferred for re-use and adaptation in another place. The concept of LO was borrowed from object oriented programming to address the issues of learning resources deconstruction and their subsequent reuse to compose larger courses or learning units (Hudak, 2007; Lim, 2007). LOs should not be 
viewed as merely "containers" of content, but as distinctive attributes of learning that can be "granular, reusable, searchable and interoperable" across different systems" to support knowledge construction and application in learning (Lim, 2007, p. 45).

\section{Course curriculum instructional/learning design}

The designing of online courses requires a radical change in thinking in the way the instruction is designed and presented to the student. Much of the instructional design (ID) that has been applied to Web-based learning environments has been guided by the principles of instructional systems design (ISD) that is driven by objectivist conceptions of design (Duffy \& Jonassen, 1992; Roblyer, 2003). Indeed, two of the dominant instructional design models that derive mostly from objectivist theories of learning are the Dick, Carey and Carey's (2005) ISD and the Analysis, Design, Develop, Implement and Evaluate (ADDIE) Model. The components of Dick, Carey and Carey's ISD approach are to: identify instructional goals, conduct instructional analysis, analyse learners and contexts, write performance objectives, develop assessment instruments, develop instructional strategy, select instructional materials, design and conduct formative evaluation of instruction and revise instruction. It is thus similar to the ADDIE Model in that it incorporates all of its phases of the ADDIE Design Model. Vrasidas (2001) has described the objectivist-rooted ID products as prescriptive, formalistic, restrictive and reductionist. A number of alternatives to objectivists tradition instructional designs were proposed that were more open and flexible, placing less emphasis on the linear direction of the ID processes advanced by objectivists (for instance, Hannafin, Land, \& Oliver, 1999; Jonassen, 1999; Mayer, 1999; Willis, 2000; Austin, 2002; Kenny, Zhang, Schwier, \& Campbell, 2005). As pointed earlier, open and flexible learning inherent in constructivist and transformative learning paradigm is a set of educational philosophies and systems, concerned with providing learners with increased choice, convenience and personalisation to suit their interests and needs. In particular, flexible learning provides learners with choices about where, when and how learning occurs (Shurville, Browne, \& Whitaker, 2008; Makrakis, 2012). Current research findings show that integrating open-ended and flexible assessment activities that were relevant to realworld applications created a contextualised learning environment that facilitated learner autonomy and active cognitive engagement (Gikandi, 2011).

Pliner and Johnson (2004) and Scott, McGuire and Shaw (2003) provide an overview of universal instructional design (UID) as an approach for addressing the diverse learning needs of students enrolled in institutions of higher education. The concept of UID is conceptually related to the principles and practices of multicultural education and social justice education. From a critical pedagogy perspective, Campbell, Schwier and Kenny (2005) propose a view of ID practice in which the instructional designer is an agent of social change at the personal, relational and institutional levels. In this view, instructional designers are not directed by managerial issues, but act in purposeful, value-based ways with ethical knowledge, in social relationships and contexts that have consequences in 
and for action. Shifting away from the decontextualised conceptions of objectivist IDs and the neglect of praxis from the constructivist conceptions of IDs, ExConTra IDs place due emphasis on values, ethics and change agency.

The instructional design for online learning we developed is driven by the ExConTra learning paradigm and partly adapted from Nam \& Smith-Jackson (2007). As seen in Figure 3, this model consists of five design phases - needs analysis, curriculum design, development, formative evaluation and implementation - each of which has its own design processes. These phases, although, placed sequentially, in practice, there is much interaction among them. For developing the M.Sc. programme as a system, we have integrated some characteristics of objectivist ISDs in order to respond to adults' preferences for a goal-oriented curriculum. The developing of course curriculum, however, is based on critical adult education (for instance, critical reflection, experiential, situated learning, praxis) that is in alignment with the ExConTra learning paradigm. Critical adult education, as a learning approach, is well situated to influence instructional design and instructional methods, that can further serve foundational principles of ExConTra learning and create space for promoting education for sustainability enabled by ICTs. Abdullah, Parasuraman, Muniapan, Koren, \& Jones (2008) summarising from other studies state that: 1) adults are autonomous and self-directed; 2) have accumulated a foundation of life experiences and knowledge; 3 ) are goal-oriented and practice oriented. They also need to be engaged in learning by doing, problem-solving tasks and activities and critical reflection during and after their activities (Frey \& Alman, 2003).

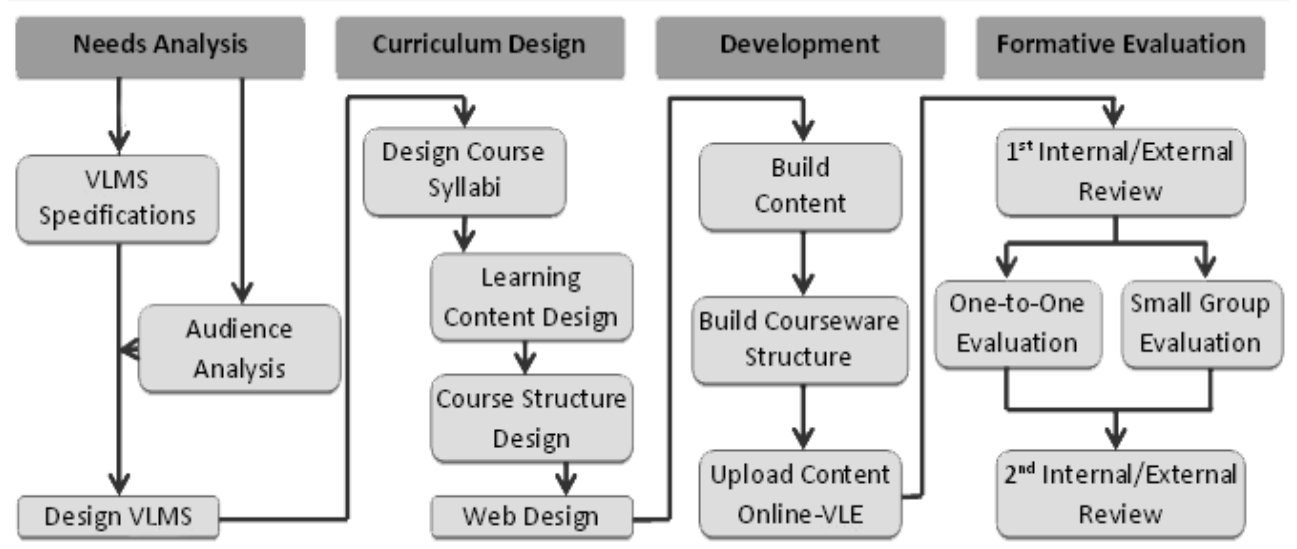

Figure 3. A model for designing course design and development

We have also identified a number of key elements related to the ExConTra learning model or paradigm and the online course design process, as exemplified in Figure 4. 


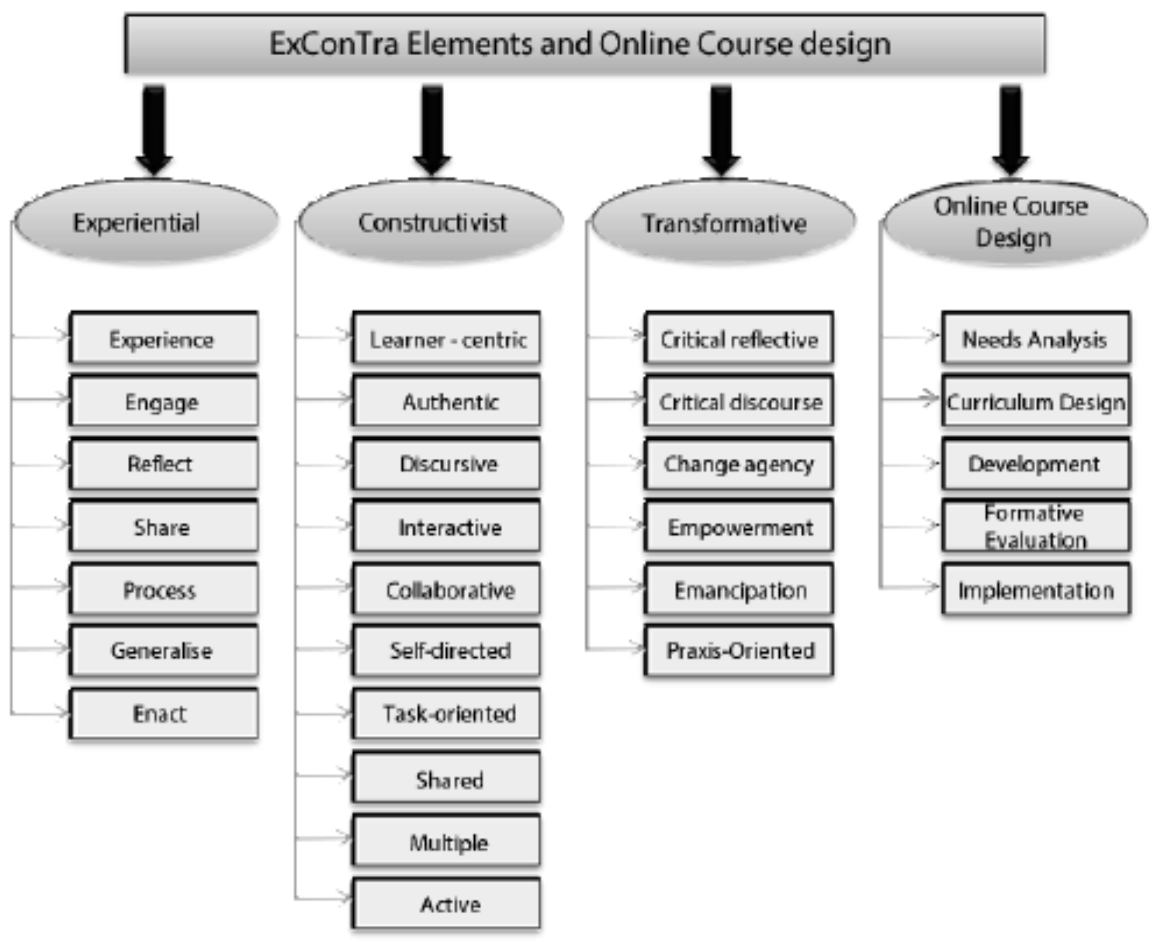

Figure 4. The ExConTra learning and online course design processes

Examples of how ExConTra learning paradigm can be implemented in online course design include the following:

- using Web-based authoring tools and scripting languages to develop learner-centred and self-instructional modules;

- providing Web-based resources using hypermedia and multimedia links to support students' experiential, constructivist and transformative learning activities;

- providing links to online databases, experts, virtual laboratories and knowledge repositories dealing with sustainable development issues;

- providing web-based distributed learning activities that allow learners to brainstorm ideas, negotiate, reflect, peer critique, debate, construct knowledge and develop action competence;

- providing synchronous and asynchronous communication tools that help the knowledge construction process through self/group critical reflection;

- incorporating learning principles and strategies that include active learning, collaboration and cooperation;

- engaging students in the application of knowledge through inquiry-based learning, problem-based learning, higher order thinking, inter/cross disciplinary learning and authentic learning; 
- identifying the learning domains and complex problems or cases to be explored within the identified learning domains;

- acknowledging learners' thoughts, experiences, ideologies and biases and encouraging them to get involved in dialogue and meaning-making, especially through student-led online discussions;

- encouraging learners in integrating LOs in the course while working with it, thus taking into consideration their needs and interests as well as their various learning styles.

In this context, a number of questions need to be posed and taken into consideration in the design process, such as: What tasks will the e-tutor complete prior to starting the learning activity? What will students have to do to prepare for the learning activity? What administrative steps will be necessary for e-tutors to take in order to manage the online learning process? What responsibilities and modes of behaviour students need to have in online learning?

\section{Applying the ExConTra instructional/learning design model}

\section{Phase 1: Needs analysis}

Needs identification is strongly linked to an analysis of a set of tasks carried out in order to respond to the needs of the targeted audience. Needs analysis was concerned with gathering, analysing and summarising information necessary to build the virtual learning management system (VLMS). This phase is consisted of three design processes: VLMS specifications, audience analysis and VLMS design. Comparative analysis of the most common virtual platforms was carried out to identify strengths and weaknesses in terms of the needs and priorities of the ICTeESD project. We decided that Moodle is the most suitable online platform. Moodle is one of the most user-friendly and flexible open source courseware products available. It has excellent documentation, strong support for security and administration and is evolving towards Instructional Management Systems/Shareable Content Object Reference Model (IMS/SCORM) standards with platform (Apache, PHP, MySQL). The key to Moodle is that it is developed with both pedagogy and technology in mind. Moodle can also be supported by Mahara, which was found to be suitable as an e-portfolio. 


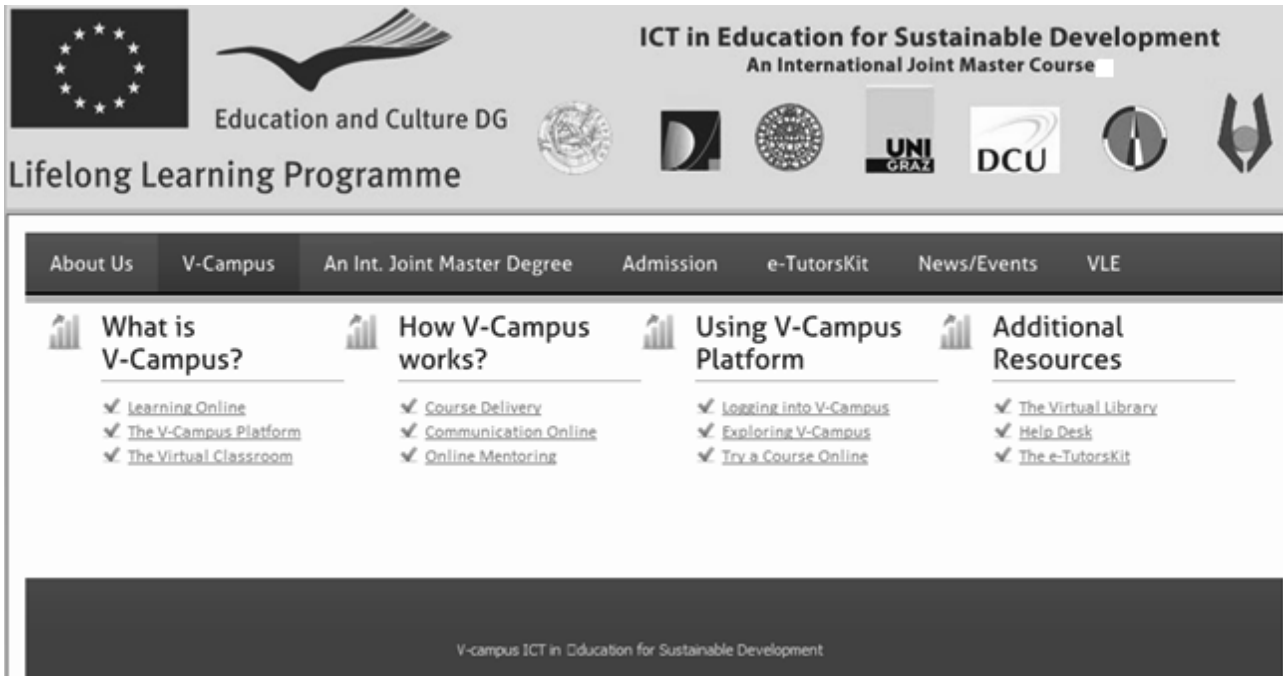

Figure 5. Introductory information screen of the virtual learning environment

A semi-structured questionnaire was also delivered to a purposeful sample $(\mathrm{N}=37)$ of prospective students to elicit various types of information such as learning styles and profiles, previous experiences with e-learning tools, learning needs, ICT literacy, technology use, etc. Small group discussions were also carried out to enable people to talk and share ideas and experiences. The information gleaned from the needs analysis helped us to define educational goals, which were stated as specific learning outcomes in the phase of curriculum design and development. In other words, this phase functioned as the foundation on which we developed course syllabi and course modules.

\section{Phase 2: Course curriculum design}

In our case, curriculum was designed and interpreted in a four-stage process: 1) design of course syllabi; 2) learning content design; 3) course structure design and 4) web design. These processes provided the foundation for the course modules development exemplified in the development phase. The first stage of the process of course curriculum design and development consisted on an extensive literature review that led to an exhaustive, as much as possible, identification of a group of themes, concepts, technologies, analysis methodologies linked to ICTs and ESD. In order to ensure that the literature review would cover the main themes, an extensive review of Masters courses related to the field of ESD was carried out in each country and region of the partner universities. A similar review was also carried in other regions worldwide. After that, another literature review was made, this time taking into consideration more specific works that allowed for a more in-depth analysis of themes and subjects identified in the previous stage.

A critical decision was made for the structure of the course curriculum. It is structured 
by merging vertical and horizontal modes of course curriculum design. The vertical integration represents continuity and structures the content in sequence from core to more complex and specialised or directed to specified streams. This provides a clear picture to learning, as students are able to understand how the knowledge is developed and organised in the course. In addition, it can help students to learn concepts and principles, to develop cognitive skills, to make choices and to develop attitudes and values that will be important to them in the working world. The vertical integration also assumed that there were discrete courses which combined content from two or more subject domains.

The horizontal integration brings about more breadth of curricular contents of different disciplinary areas and knowledge domains, especially through an interdisciplinary approach within the course areas. In this sense transformative learning cuts across all the five competences (learning to be, learning to know, learning to live together, learning to do and learning to transform oneself and society), and it requires infusion among the disciplines, the university and the wider community, in order for the learners to function as agents of change. An interdisciplinary approach always consciously combines two or more subjects, while it keeps them distinct and in focus. Horizontally, the courses were built conceptually upon five main themes: sustainability theory; educational research; ESD pedagogy; educational policy and leadership; information \& communication technology. The emphases were on: 1) inter/crossdisciplinary content by merging concepts from the main themes and 2) multidisciplinary content by integrating multiple teaching methods and learning technologies. In this context, ICTs and ESD form the integrating 'backbone' across all course contents. The design of the online curriculum components departed from the students' needs that were contingent on the needs analysis processes. Twelve course syllabi were developed using a template for designing online course syllabi.

Table 1. The course structure of the Masters programme

\begin{tabular}{lc}
\hline Programme of study & ECTS \\
\hline Year 1 Semester 1 & 30 \\
\hline Sustainability Theory, Systems Thinking and Transformative Change & 10 \\
\hline Approaches to Educational Research for Sustainable Development & 10 \\
\hline ESD Pedagogy and ICT & 10 \\
\hline Year 1 Semester 2 & 30 \\
\hline Appropriate Technology, Active Citizenship and Education for Sustainable & 10 \\
Development & 10 \\
\hline $\begin{array}{l}\text { Action Research and Participatory Action Research for Sustainable } \\
\text { Development }\end{array}$ & 10 \\
\hline $\begin{array}{l}\text { ICT, Instructional/Learning Design and Education for Sustainable } \\
\text { Development }\end{array}$ & 60 \\
\hline Year 2 Semester 1 (to be chosen 3 out of 6) & 10 \\
\hline Educational Policy and Planning for Sustainable Schooling
\end{tabular}

Sequel to Table 1 see on p. 26. 
Sequel to Table 1.

\begin{tabular}{lc}
\hline ICT, Climate Change and Geo-spatial Tools & 10 \\
\hline Bio-cultural Diversity and Education for Sustainable Development & 10 \\
\hline e-Learning, Virtual Worlds and Education for Sustainable Development & 10 \\
\hline Teaching to Live Sustainably through the Earth Charter & 10 \\
\hline $\begin{array}{l}\text { Sustainable Leadership, Inter/Cross Cultural Communication and Planning } \\
\text { for Sustainability }\end{array}$ & 10 \\
\hline Year 2 Semester 2 & 30 \\
\hline Dissertation & 30 \\
\hline Total for the Masters degree & 150 \\
\hline Total for the Masters degree needed & 120 \\
\hline
\end{tabular}

\section{Phase 3: Development}

Learning content was based on an instructional design process for curriculum development which involved a systematic approach to establishing course modules' goals and objectives, selecting educational strategies to meet goals and objectives, the use of media and technology as well as designing learning activities for the online environment. Course structure process was based on breaking-up the course into manageable and meaningful modules and units, taking into consideration the weekly topics designed in the corresponding course syllabus. An example of a course modules template is provided in Figure 6. To achieve this purpose, first, the course was logically divided into modules, each module containing units, learning outcomes and learning activities that open space for learners to control their learning and enrich the content of the course enabled by appropriate online technologies.

\begin{tabular}{|c|c|c|}
\hline Course & \multicolumn{2}{|l|}{ TITLE } \\
\hline Module 1 & \multicolumn{2}{|l|}{ Title } \\
\hline \multicolumn{3}{|c|}{ Key Concepts } \\
\hline \multicolumn{3}{|l|}{ Overview } \\
\hline \multicolumn{3}{|l|}{ Aim } \\
\hline \multicolumn{3}{|l|}{$\begin{array}{l}\text { Learning } \\
\text { Outcomes }\end{array}$} \\
\hline \multicolumn{3}{|l|}{ Units } \\
\hline \multicolumn{3}{|l|}{ Readings } \\
\hline \multirow[t]{9}{*}{ Activities } & & \\
\hline & \multicolumn{2}{|l|}{ Overview } \\
\hline & \multicolumn{2}{|l|}{ Explanation } \\
\hline & Module 1 & Time-loa \\
\hline & $\begin{array}{l}\text { Directed Learning Online } \\
\square\end{array}$ & \\
\hline & $\begin{array}{l}\text { Dynamic Interaction online } \\
\square\end{array}$ & \\
\hline & $\begin{array}{l}\text { Assessment } \\
\square \\
\text { [Note: Time allowed for preparing Assessment work can } \\
\text { vary from } 1-7 \text { hours on average per module] }\end{array}$ & \\
\hline & $\begin{array}{l}\text { Independent Learning } \\
\square \\
\text { [Note: Time available to spend on Independent learning } \\
\text { can vary from } 1-7 \text { hours on average per module] }\end{array}$ & \\
\hline & Total Time for Module 1 & \\
\hline
\end{tabular}

Figure 6. The template for the course modules design 
As pointed earlier, some aspects of the objectivist instructional design were adopted that were merged with ExConTra learning design principles. In particular, learning objectives for course modules were pre-specified, taking into consideration the needs analyses and group expertise from course modules' writers and designers. In consistency with the ExConTra learning, activities were largely designed based on the choice of ill-structured problems that require the integration of several content domains. Asynchronous discussions are integrated within learning activities that can allow students time to read, think, reflect and reply. Indeed, peer discussion is one of the essential elements in ExConTra learning, especially in collaborative tasks.

The learning activities provide students with the capacity to explore, inquire and reflect on their thoughts, believes, values and practices enabled through synchronous and asynchronous communication tools. Such tools could be used to foster interaction and the sense of belonging in a learning community and minimise the sense that students are isolated from each other. Synchronous chat discussion groups are used for brainstorming, debating, clarifying values while the e-tutor functions as a coach and facilitator encouraging teams to reflect on their beliefs and to consider alternative interpretations of the issues and problems studied. Particular emphasis was placed on integrating technologies (virtual worlds/games, blog, stream media) to encourage students create like-real situations. Students are also involved in reading and analysing team members' responses and providing appropriate feedback. Peerto-peer interactions and dialogue about challenging ESD concepts and problem solving is the focus of learning activities design enabled by ICTs. Students are encouraged to construct part of their knowledge via interaction with each other and this knowledge to be considered part of the course content. In this way, students are turned into co-constructors of what to be learned and how it would be learned. In order to provide proper scaffolding and coaching, the e-tutor is monitoring student-led team conversations as an equal partner in the learning process.

In order to prompt learners to investigate the problem, a list of focusing questions and information resources (for instance, suggested readings, links to related internet sites and other information resources) are provided. As indicated in the ExConTra learning model, one of the key principle is collaboration and shared knowledge. In learning activities, the problem or case is presented as a collaborative team activity in which students are asked to set up teams, divide roles, share responsibilities and tasks in identifying alternatives, clarifying alternatives, comparing and contrasting alternatives before reaching a consensus for a decision. They are also presented with a complex or real-life problem by using learning objects as problem statements or scenarios. Simple and complex digital learning objects provided as open education resources and open source software are integrated in learning activities to activate ExConTra learning. Another powerful knowledge construction strategy integrated into learning activities is encouraging learners to construct their own learning objects enabled through various tools and online technologies. This generative strategy enables students to design and link interrelated content and ideas in the form of meaningful content structures. 
This gives more opportunities for: 1) integrating varied examples of how different disciplines can be merged within a single subject; 2) interacting during problem solving activities; 3 ) engaging in a reflective conversation and 4) selecting, re-using and adapting digitised learning objects identified in the internet. The strategy to involve also students in team-based learning activities from different socio-cultural contexts, despite empowering them to reflect on their thoughts and practices and analyse their own lives, may break down the stereotypes that others may have of them.

\section{e-Tutors' toolkit}

With a growing number of courses and degrees offered through the internet, there is a considerable interest in preparing instructors to teach online. A pedagogically meaningful and replicable toolkit for virtual training has also been developed and applied in training teaching staff to function as e-tutors for the joint Masters degree programme. Building content included the development of learning activities, learners' assessment, types of learners' communication and interaction. Much of the course materials are based on learning objects which represent either autonomous learning and/or modified or newly developed. The ICTeESD e-tutors toolkit targets prospective e-tutors nominated by the partner universities to support the ICTeESD M.Sc. programme on ICTs in education for sustainable development.

The e-tutors toolkit is a self-development manual based on ICTeESD materials/tools and open education resources supported by facilitators and designed to assist participants make the shift from face-to-face forms of teaching and learning to online learning. The toolkit has the following six modules, which are integrated into the main themes of the dedicated website.

Module 1: Getting started with the ICTeESD Moodle-based virtual learning environment.

Module 2: Becoming an e-tutor.

Module 3: Orientation to online teaching \& learning.

Module 4: Building a community of online learners.

Module 5: Developing online activities.

Module 6: Wrapping up all.

Modules 1 and 2 provide participants with the competences needed to become comfortable with the ICTeESD Moodle-based virtual learning environment and an exploration of the characteristics, roles and competences of being an e-tutor. Module 3 provides an orientation to the characteristics, pedagogies and technologies for online teaching and learning. Modules 4 and 5 integrated into the theme "Practising e-tutoring" engage participants in designing, organising, scaffolding, communicating and assessing online learning. Finally, Module 6 wraps up all with an assessment of the whole training process. 


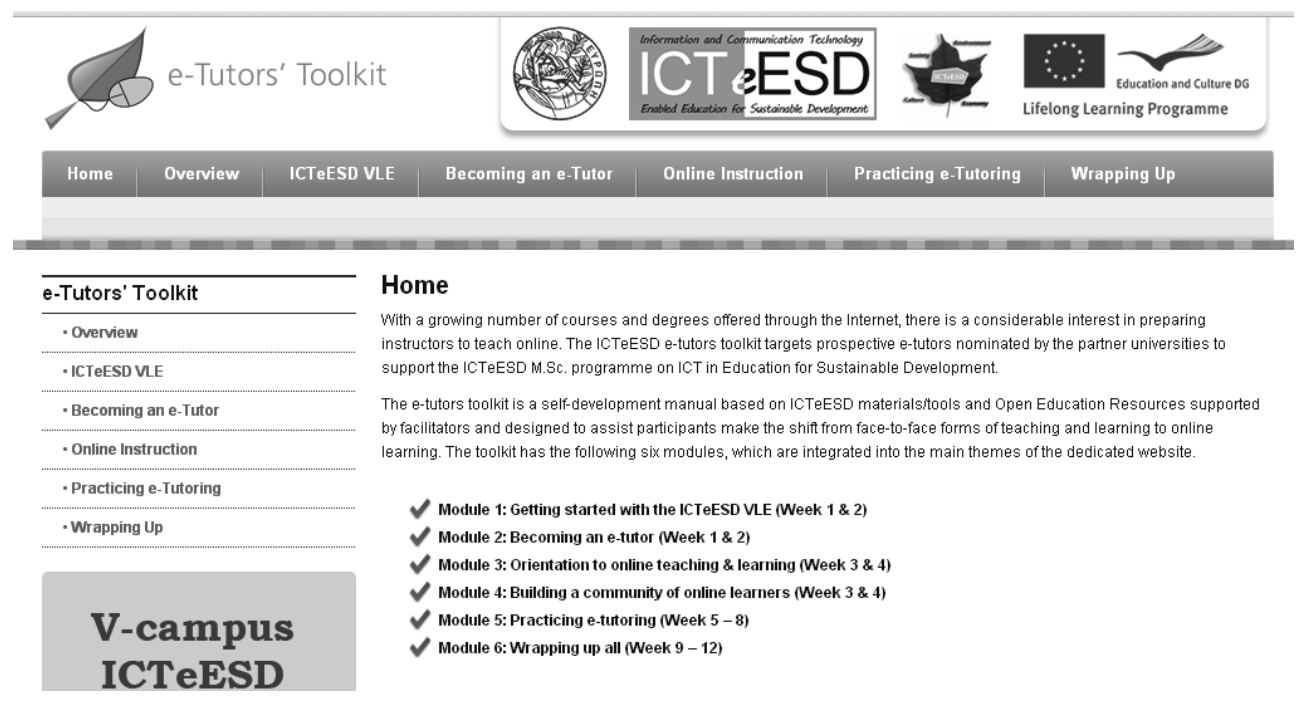

Figure 7. The introductory screen of the e-tutors toolkit

\section{Phase 4: Formative evaluation}

Formative evaluation refers to a process that provides a judgment of the strengths and weaknesses of all the activities involved in the online course across all design and developing stages to improve its effectiveness and appeal. The concept of formative assessment is underpinned by three defining processes: "establishing where the learners are in their learning [in relation to the expected learning outcomes]; establishing where they are going; and establishing what needs to be done to get them there" (Black \& Wiliam, 2009, p. 7). Effective integration of online formative assessment has the potential to facilitate and sustain meaningful interactions among learners and the teacher and, in turn, foster development of effective learning communities to support meaningful learning and its assessment (Sorensen \& Takle, 2005). Moreover, this can provide a systematic structure for effective support and learning scaffold through ongoing monitoring of learning and provision of adequate formative feedback.

Our purpose was to provide evidence to be used in making decisions about how to review and revise the programme while it is being developed. It is worth pointing out that our literature review that was carried in the need analysis phase in this field barely revealed any course curriculum design that has holistically integrated online formative assessment, especially from the perspectives of supporting meaningful learning. The formative evaluation process advanced in the ICTeESD project consisted of four processes: 1) 1st internal/external review; 2) one-to-one evaluation; 3) small group evaluation; 4) 2nd internal/external evaluation. The 1st internal/external review is designed to take place up to the third phase, covering all processes involved. The one-to-one and small group evaluation processes make use of prospective students as subjects. It includes a series of usability tests, peer reviews or expert reviews in any of the previous phases and processes. 


\section{Quality assurance}

Quality assurance in the ICTeESD project has two directions. The first direction concerns the strategies to be adopted in order to ensure quality, and the second direction concerns the process of accreditation and recognition of the Masters programme. Both of these directions are not mutually exclusive, as the first is a condition for the second. One of the main concerns revealed in EUA (2006) Joint Masters Project (2002-2004) is the often weak anchoring of joint Masters programmes within their network institutions. This is explained by the fact that such programmes are mostly initiated and linked to committed individuals, while the institution as an 'outsider' has often provided difficulties to endorse the programme. Another important finding in EUA's Joint Masters Project was the incompatibility of the national mandate of quality assurance agencies with the transnational nature of joint degrees. In addition, with regard to internal quality processes, the nature, maturity and standards of the institutions involved on which they are based vary across Europe. However, as the proposal for the joint degree is endorsed by all partner institutions, recognition of the degree may be made contingent on all member institutions or programmes of the group or consortium.

It was thus important to assure that ICTs in ESD Masters programme led by the ICTeESD project coordinated by the University of Crete meets the qualities needed to gain recognition outside of those involved in its conception and development. A major effort was exerted in systematising and organising curricular contents in order to ensure that the curricular components are aligned with the learning activities, the curriculum global objectives and competencies to promote. This systematising and organisation process of the curricular contents is not an easy task for various reasons. To this end, a quality assurance framework has been developed that illustrates a comprehensive coverage of key components of online course quality assurance depicted in Figure 8 (Makrakis \& Kostoulas-Makrakis, 2012b).

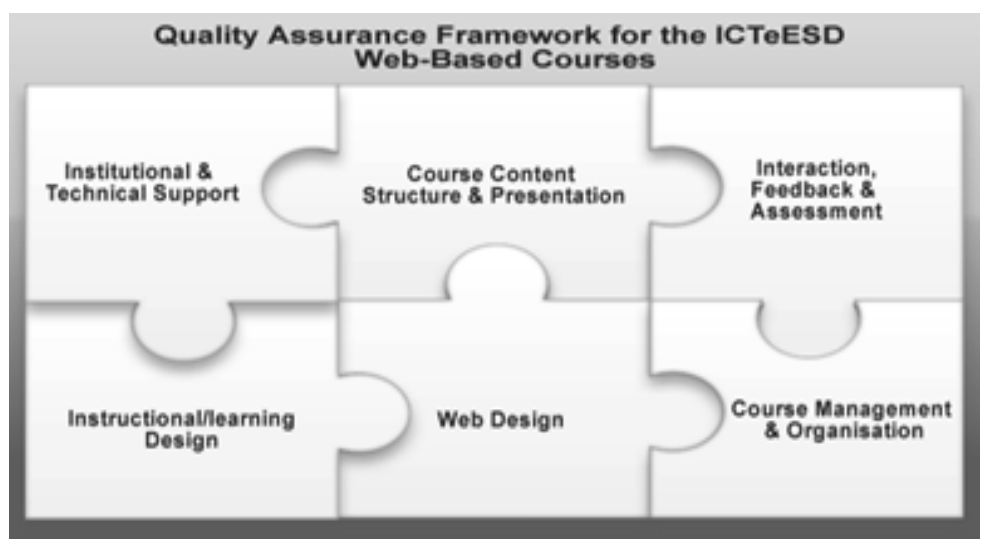

Figure 8. Quality assurance framework 
It serves as a blueprint for addressing the issues for online course design. The framework consists of six independent but interconnected components, which are further divided into relevant sub-components. Missing one piece means missing part of the puzzle that, when complete, provides an overview of quality issues in online courses.

Each sub-component includes a number of benchmarks that can be used as reference points for assessing the quality of every key component (Table 2). It should be borne in mind, however, that the development of quality standards is a complex and not an easy task as the developments in the area of online education have still not reached maturity (Galloway, 2005). The need for standards that could guide online higher education and the design and delivery of online courses continue to be one of the most critical factors for open distance and flexible learning enabled through web-based and other advanced technologies (Allen \& Seaman, 2005). There is clear agreement that online education has specific characteristics which should be considered in designing any quality assurance instrument for online course design and development.

Table 2. Quality assurance instrument for online course design and development

\begin{tabular}{ll}
\hline Instructional/Learning Design & Course Content Structure and Presentation \\
\hline Students' readiness & Structuring the course \\
Course \& module goals \& objectives & Functionality and consistency \\
Learning activities & Text structure and formatting \\
Learning Strategies & Providing adequate feedback \\
\hline Interaction, Feedback \& Assessment & Institutional Policies and Technical Support \\
\hline Interaction among learners & Accessibility \\
Interaction between learners and & Authentication and security \\
instructor & Copyright, netiquette \\
Interaction between learners and & \\
instructional materials & \\
Feedback and assessment & \\
\hline Web Design & Course Management and Organisation \\
\hline Understanding user needs & Time requirements \\
Navigation & Progression through course \\
Visual appearance & Providing adequate feedback \\
\hline
\end{tabular}

\section{Concluding remarks}

Our focus in this paper was the design and development of a VLE for a M.Sc. programme on ICT in education for sustainable development driven by a learning paradigm that merges three theories of learning, namely: experiential learning, constructivist learning and transformative learning (ExConTra). While, for instance, ICTs can provide interactive mind/cognitive tools to support learning and develop new understandings and knowledge in areas of teaching and learning for sustainability, ESD themes integrated into the school curricula could provide a worthwhile context for ICTs in education (Makrakis, 2010abc). Such themes may include cultural diversity and intercultural/interfaith understanding, health, HIV/AIDS, governance, natural resources, climate change, rural development, 
sustainable urbanisation, disaster prevention and mitigation, poverty reduction, corporate responsibility and accountability and so forth. In this sense, social, economic and environmental issues can provide meaningful and challenging contexts for developing a wide range of ICT skills. Activities were designed to meet students' various learning styles and encourage them to experience personal change towards learning to live sustainably. The questions asked of online tutors encourage students to express their thoughts andtake control of their learning, allow them to share their thoughts and ideas, listen to the perspectives of others and critically reflect on their own viewpoints.

Using a participatory curriculum development approach ensures that all the groups and individuals who have a real interest in the programme are actively involved in some way in the project during various stages. In this way, prospective students, instructional designers, content experts, critical readers and prospective e-tutors were involved in the course curriculum development. Through this approach contextualised teaching and learning becomes more feasible, as those involved bring their own experiences to the learning process. Such an approach is also conducive to the 'process' and 'praxis' curriculum approach that is characterised by the recognition of empowerment, emancipation, knowledge construction, meaning making and negotiation. A participatory and negotiated curriculum, however, does not necessarily imply that every facet of the curriculum is open to participation and negotiation.

This learning paradigm used allows both online students and facilitators to take advantage of ICT tools and the World Wide Web on making connections and making meaning in the learning process. Online students can collaborate by sharing their individual perspectives, ideas and personal experiences, thereby deepening their understanding with increasing higher order thinking and greater personal satisfaction (Engstrom, Santo, \& Yost, 2008). When used in conjunction with instructional methods that promote inquiry and collaboration, technological solutions become important components to facilitating experiential learning (Meyers, 2008). A rich learning environment encourages shared meaning and shared inquiry (Novak, 1998) as well as multiple learning styles and multiple representations of knowledge (Kafai \& Resnick, 1996). Pre-specified learning activities combined and enriched with the materials created by students cater for several learning styles and interactions (student-teacher; student-student; student-content). The ExConTra learning process is also based on an interdisciplinary approach addressing the four pillars (environment, society, culture and economy) of sustainable development and makes use of an online course design methodology that uses four phases: needs analysis, curriculum design, development and formative evaluation. The VLE that encompasses both the curriculum programme and the online platform with its tools and online technologies merges ICTs with ESD in three ways: a) providing opportunities to target groups for reflective practice; b) using open source ICT tools and ESD-related learning objects available in the Web and c) using ICTs to develop interactive, interdisciplinary and cross-disciplinary ESD learning activities. 


\section{Acknowledgement:}

This work has been developed within the framework of the ICTeESD project that has been funded from the European Commission (ERASMUS Multilateral Programme Virtual Campus Project No. 510212-LLP-1-2010-1-GR-ERASMUS-EVC (2010-3494). The content of the paper reflects the views of the authors, and the Commission cannot be held responsible for any use which may be made of the information contained therein.

\section{References:}

Abdullah, M., Parasuraman, B., Muniapan, B., Koren, S., \& Jones, M. L. (2008). Motivating factors associated with adult participation in distance learning program. International Education Studies, 1(4), 104-109.

Allen, I. E., \& Seaman, J. (2005). Growing by degrees: Online education in the United States, 2005. Retrieved August 5, 2012, from http://www.sloan-c.org/resources/growing_by_ degrees.pdf

Aristotle. (2004). The Nicomachean ethics. (J. A. K. Thomson, trans.). London: Penguin.

Austin, A. E. (2002). Creating a bridge to the future: Preparing the new faculty to face changing expectations in a shifting context. The Review of Higher Education, 26(2), 119-144.

Black, P., \& Wiliam, D. (2009). Developing the theory of formative assessment. Educational Assessment, Evaluation \& Accountability, 21(1), 5-31. DOI: 10.1007/s11092-008-9068-5.

Bush, M. D., \& Mott, J. D. (2009). The transformation of learning with technology: Learnercentricity, content and tool malleability, and network effects. Educational Technology, 49(3), $3-20$.

Campbell, K., Schwier, R. A., \& Kenny, R. F. (2005). Agency of the instructional designer: Moral coherence and transformative social practice. Australasian Journal of Educational Technology, 21(2), 242-262. Retrieved January 30, 2012, from http://www.ascilite.org.au/ ajet/ajet21/campbell.html

Cey, T. (2001). Moving towards constructivist classroom. Retrieved December 19, 2009, from http://www.usask.ca/education/coursework/802papers/ceyt/ceyt.htm

Cranton, P. (1994). Understanding and promoting transformative learning: A guide for educators of adults. San Francisco: Jossey-Bass.

Daley, D. M. (1991). Great expectations or a tale of two systems: Employee attitudes toward graphic rating scales \& MBO-based performance appraisal. Public Administration Quarterly, 15(2), 188-209.

Darder, A., Baltodano, M., \& Torres, R. D. (2003). The critical pedagogy reader. London: Routledge Falmer.

Dick, W., Carey, L., \& Carey, J. O. (2005). The systematic design of instruction (6th ed.). New York: Allyn and Bacon. 
De Haan, G. (2006). 'The BLK '21' programme in Germany: A 'Gestaltungskompetenz' based model for education for sustainable development'. Environmental Education Research, 12(1), 19-32.

Duffy, T. M., \& Jonassen, D. H. (1992). Constructivist and the technology of instruction: A conversation. Hillsdale, NJ: Lawrence Erlbaum Associates.

Elliott, J. (2010). Insights to transformative learning through education for sustainable development. Learning and Teaching in Higher Education, 5, 96-113.

Engstrom, M., Santo, S., \& Yost, R. (2008). Knowledge building in an online cohort. The Quarterly Review of Distance Education, 9(2), 151-167.

European University Association. (2006). Guidelines for quality enhancement in European joint master programmes. Retrieved February 20, 2012, from http://www.eua.be/eua/jsp/ en/upload/EMNEM_report.1147364824803.pdf

Fien, J., \& Tilbury, D. (1996). Learning for a sustainable environment: An agenda for teacher education in Asia and the Pacific. Bangkok: UNESCO.

Freire, P. (1993). Pedagogy of the oppressed. New York: Continuum.

Frey, B., \& Alman, S. (2003). Applying adult learning theory to the online classroom. New Horizons in Adult Education, 17(1), 4-12. Retrieved July 10, 2011, from http://education. fiu.edu/newhorizons/journals/volume17n1.pdf

Galloway, D. (2005). Evaluating distance learning and e-learning: Is Kirkpatrick's model relevant?. Performance Improvement, 44(4), 21-27. DOI: 10.1002/pfi.4140440407.

Garvin, D. A. (2000). Learning in action: A guide to putting the learning organization to work. Boston, MA: Harvard Business School Press.

Gikandi, J. (2011). Achieving meaningful online learning through effective formative assessment. In G. Williams, P. Statham, N. Brown \& B. Cleland (Eds.), Changing demands, changing directions (pp. 452-454). Retrieved March 15, 2012, from http://www.ascilite. org.au/conferences/hobart11/procs.Gikandi-poster.pdf

Giroux, H. (n.d.). Teachers as transformatory intellectuals. Symposium on understanding quality education. Conference on re-envisioning quality education. Retrieved March, 15, 2012, from http://www.afed.itacec.org/document/henry_giroux_2_ok.pdf

Giroux, H. (1988). Teachers as intellectuals. Boston, MA: Bergin \& Garvey.

Glasser, H. (2007). Minding the gap: The role of social learning in linking our stated desire for a more sustainable world to our everyday actions and policies. In A. E. J. Wals, (Ed.), Social learning towards a sustainable world. Principles, perspectives, and praxis (pp. 35-62). Wageningen, The Netherlands: Wageningen Publishers.

Grundy, S. (1987). Curriculum: Product or praxis. New York: The Falmer Press.

Habermas, J. (1971). Knowledge and human interests. London: Heinemann.

Hannafin, M., Land, S., \& Oliver, K. (1999). Open learning environments: Foundations, 
methods and models. In C. M. Reigeluth (Ed.), Instructional-design theories and models, Volume II: A new paradigm of instructional theory (pp. 115-140). Mahwah, NJ: Lawrence Erlbaum Associates.

Hasselbring, T. S., \& Moore, P. R. (1996). Developing mathematical literacy through the use of contextualized learning environments. Journal of Computing in Childhood Education, $7(3 / 4), 199-222$.

Huckle, J. (1996). Realising sustainability in changing times. In J. Huckle \& S. Sterling (Eds.), Education for sustainability (pp. 3-17). London, UK: Earthscan Publications.

Huckle, J. (2008). An analysis of new labour's policy on education for sustainable development (ESD) with particular reference to socially critical approaches. Environmental Education Research, 14(1), 65-75.

Huckle, J. (2012). Teacher education for sustainability in network society: Combining digital and sustainability literacies. Journal of Teacher Education for Sustainability, 14(2), 130-146.

Hudak, C. (2007). Linking instructional theories and instructional design to leaning objects: A proposed conceptual framework. In A. Koohang \& K. Hamman (Eds.), Learning objects and instructional designs (pp. 1-38). Santa Rosa, California: Informing Science Press.

Jonassen, D. H. (1991). Objectivist vs. constructivist: Do we need a new philosophical paradigm? Educational Technology: Research and Development, 39(3), 5-14.

Jonassen, D. H. (1994). Thinking technology. Educational Technology, 34(4), 34-37.

Jonassen, D. H. (1999). Designing constructivist learning environment. In C. M. Reigeluth (Ed.), Instructional design theories and models (Vol. 2, pp. 215-239). Mahwah, NJ: Erlbaum Associates.

Jonassen, D. H., \& Reeves, T. C. (1996). Learning with technology: Using computers as cognitive tools. In D. H. Jonassen (Ed.), Handbook of research on educational communications and technology (pp. 693-719). New York: Macmillan.

Jonassen, D. H., Peck, K. L., \& Wilson, B. G. (1999). Learning with technology: A constructivist perspective. Upper Saddle River, NJ: Merrill Publishing.

IAU (International Association of Universities). (2006). Selected bibliography on education and sustainable development. Retrieved October 14, 2011, from http://www.UNESCO. org/iau/sd/sd_bibliography.html

Kafai, Y., \& Resnick, M. (Eds.). (1996). Constructionism in practice: Designing, thinking and learning in a digital world. Mahwah, NJ: Lawrence Erlbaum.

Kanuka, H., \& Anderson, T. (1999). Using constructivism in technology-mediated learning: Constructing order out of the chaos in the literature. Radical Pedagogy, 2(1). Retrieved July 5, 2008, from http://www.icaap.org/RadicalPedagogy/content/vol1.1999/ issue2/02kanuka1_2.html

Kenny, R. F., Zhang, Z., Schwier, R. A., \& Campbell, K. (2005). A review of what instructional 
designers do: Questions answered and questions not asked. Canadian Journal of Learning and Technology, 31(1), 9-26.

Kolb, D. A. (1984). Experiential learning: Experience as the source of learning and development. Upper Saddle River, NJ: Prentice Hall.

Kolb, A. Y., \& Kolb, D. A. (2005). Learning styles and learning spaces: Enhancing experiential learning in higher education. Academy of Management Learning \& Education, 4(2), $193-$ 212.

Lave, J., \& Wenger, E. (1991). Situated learning: Legitimate peripheral participation. Cambridge: Cambridge University Press.

Lim, G. (2007). Instructional design and pedagogical consideration for the ins-and-outs of learning objects. In A. Koohang \& K. Hamman (Eds.), Learning objects and instructional designs (pp. 89-137). Santa Rosa, California: Informing Science Press.

Makrakis, V. (2006). Preparing United Arab Emirates teachers for building a sustainable society. Heraklion: University of Crete.

Makrakis, V. (2008). An instructional design module of ICT that empowers teachers to integrate education for sustainable development across the curriculum. In C. Angeli \& N. Valanides (Eds.), Proceedings of the 6th Panhellenic Conference with International Participation on Information and Communication Technologies in Education (pp. 391398). Cyprus: University of Cyprus.

Makrakis, V. (2010a). The challenge of WikiQuESD as an environment for constructing knowledge in teaching and learning for sustainable development. Discourse and Communication for Sustainable Education, 1(1), 50-57.

Makrakis, V. (2010b). Strategies to reinforce the role of ICT in teaching and learning for sustainability. In M. Witthaus, K. Candless \& R. Lambert (Eds.), Tomorrow today (pp. 169-171). Leicester: Tudor Rose on behalf of UNESCO.

Makrakis, V. (2010c). ICT-enabled reorienting teacher education to address sustainable development: A case study. In T. Jimogiannis (Ed.), Proceedings of the 7th Panhellenic Conference ICT in Education (pp. 1-8). Korinthos: University of Peloponnese.

Makrakis, V. (2011a). Strategies for change towards sustainability in tertiary education supported by ICT. In ICT in teacher education: Policy, open educational resources and partnership (pp. 152-166). Moscow: UNESCO Institute for Information Technologies in Education.

Makrakis, V. (2011b). ICT-enabled education for sustainable development: Merging theory with praxis. In M. Youssef \& S. Aziz Anwar (Eds.), Proceedings of the 4th Annual Conference on e-Learning Excellence in the Middle East 2011 - in Search of New Paradigms for reEngineering Education (pp.410-419). Dubai, UAE: Hamdan Bin Mohammed e-University.

Makrakis, V. (2012). Critical issues for the course curricular design and development of postgraduate programmes. Proceedings of International Forum "Modern Information Society 
Formation: Problems, Perspectives, Innovation Approaches" (pp. 85-107). Saint-Petersburg: Saint Petersburg State University of Aerospace Instrumentation.

Makrakis, V., \& Kostoulas-Makrakis, N. (2005). Techno-sciences and mathematics: Vehicles for a sustainable future and global understanding. Proceedings of the 2nd International Conference on Hands on Science. HSci 2005 (pp. 103-108). Heraklion: University of Crete.

Makrakis, V., \& Kostoulas-Makrakis, N. (2012a). The challenges of ICTs to online climate change education for sustainable development: The ExConTra learning paradigm. In S. A. Anwar (Ed.), Proceedings of the 5th Conference on eLearning Excellence in the Middle East - Sustainable Innovation in Education (pp. 594-605). Dubai, UAE: Hamdan Bin Mohammed e-University.

Makrakis, V., \& Kostoulas-Makrakis, N. (2012b). Online course design for a joint M.Sc. programme on ICT in education for sustainable development. In S. A. Anwar (Ed.), Proceedings of the 5th Conference on eLearning Excellence in the Middle East - Sustainable Innovation in Education (pp. 627-636). Dubai, UAE: Hamdan Bin Mohammed e-University.

Makrakis, V., Kostoulas-Makrakis, N., \& Kanbar, N. (2012). Developing and validating an ESD student competence framework: A Tempus-RUCAS initiative. In S. A. Anwar (Ed.), Proceedings of the 5th Conference on eLearning Excellence in the Middle East - Sustainable Innovation in Education (pp. 585-594). Dubai, UAE: Hamdan Bin Mohammed e-University.

Marsick, V., \& Mezirow, J. (2002). New work on transformative learning. Teachers college record. Retrieved September 20, 2008, from http://www.tcrecord.org/content. asp? contentid $=10876$

Mayer, R. H. (1999). Designing instruction for constructivist learning. In C. M. Reigeluth (Ed.), Instructional design theories and models: New paradigm of instructional theory (Vol. 2, pp. 141-159). Mahwah, NJ: Lawrence Erlbaum Associates.

McLaren, P. (1994). Life in schools: An introduction to critical pedagogy in the foundations of education. New York: Longman.

Mezirow, J. (2000). Learning to think like an adult: Core concepts of transformation theory. In J. Mezirow (Ed.), Learning as transformation: Critical perspectives on a theory in progress (pp. 3-34). San Francisco, CA: Jossey-Bass.

Mezirow, J. (2003). Transformative learning as a discourse. Journal of Transformative Education, 1(1), 58-63.

Meyers, S. (2008). Using transformative pedagogy when teaching online. College Teaching, 56(4), 219-224. DOI: 10.3200/CTCH.56.4.219-224.

Nam, C. S., \& Smith-Jackson, T. L. (2007). Web-based learning environment: A theory-based design process for developopment and evaluation. Journal of Information Technology Education, 6, 23-43. 
Novak, J. (1998). Learning, creating and using knowledge: Concept maps as tools to understand and facilitate the process in schools and corporations. Mahwah, NJ: Lawrence Erlbaum Assoc.

O'Neill, G. (2010). Initiating curriculum revision: Exploring the practices of educational developers. International Journal for Academic Development, 15(1), 61-71. DOI: 10.1080/13601440903529927.

Oppermann, R., \& Specht, M. (2006). Situated learning in the process of work. In D. Hung \& M. S. Khine (Eds.), Engaged learning with emerging technologies (pp. 69-89). Berlin: Springer Verlag.

O'Sullivan, E. (2003). Bringing a perspective of transformative learning to globalized consumption. International Journal of Consumer Studies, 27(4), 326-330. DOI: 10.1046/j.1470-6431.2003.00327.x.

Paas, L. (2008). How information and communications technologies can support education for sustainable development. Current uses and trends. Manitoba Canada: IISD.

Pliner, S. M., \& Johnson, J. R. (2004). Historical, theoretical, and foundational principles of universal instructional design in higher education. Equity \& Excellence in Education, 37(2), 105-113. DOI: 10.1080/10665680490453913.

Roblyer, M. D. (2003). Integrating educational technology into teaching (3rd ed.). Upper Saddle River, NJ: Pearson Education, Inc./Merrill Prentice Hall.

Rychen, S., \& Salganick, L. (2003). A holistic model of competence. In S. Rychen \& L. Salagnick (Eds.), Key competencies for a successful life and a well-functioning society (pp. 41-62). Gottingen: Hogrefe \& Huber.

Savery, J. R., \& Duffy, T. M. (1996). Problem-based learning: An instructional model and its constructivist framework. In B. G. Wilson (Ed.), Constructivist learning environments: Case studies in instructional design (pp. 135-148). New Jersey: Educational Technology Publications.

Schmidt, A. (2005). Bridging the gap between knowledge management and e-learning with context-aware corporate learning solutions In K. Althoff, A. Dengel, R. Bergmann, M. Nick $\&$ T. R. Berghofer (Eds.), Professional knowledge management. Third biennial conference (pp. 203-213). WM 2005, Kaiserlautern, Germany: Springer.

Schmidt, A. (2008). Enabling learning on demand in semantic work environments: The learning in process approach In J. Rech, B. Decker \& E. Ras (Eds.), Emerging technologies for semantic work environments: Techniques, methods and applications (pp. 1-21). Hershey, PA: IGI Publishing.

Schmidt, A., \& Braun, S. (2006). Context-aware workplace learning support: Concept, experiences, and remaining challenges. In W. Nejdl \& K. Tochtermann (Eds.), Innovative approaches for learning and knowledge sharing. First European Conference on TechnologyEnhanced Learning (EC-TEL 2006) (pp. 518-524). Crete, Greece: Springer. 
Scott, S. S., McGuire, J. M., \& Shaw, S. F. (2003). Universal design for instruction: A new paradigm for adult instruction in postsecondary education. Remedial and Special Education, 24(6), 369-379.

Seitz, K., \& Schreiber, J. R. (2005). Towards sustainable development - learning for a world qualified for the future. A discussion paper of the Association of German development nongovernmental organisations (VENRO) on the UN Decade of Education for Sustainable Development 2005-2014. VENRO-working paper No. 15.

Shurville, S., Browne, T., \& Whitaker, M. (2008). Employing educational technologists: A call for evidenced change. In Hello! Where are you in the landscape of educational technology? Proceedings of ASCILITE Melbourne 2008. Retrieved May 6, 2010, from http://www. ascilite.org.au/conferences/melbourne08/procs/shurville.pdf

Smith, M. K. (2000). Curriculum theory and practice. The encyclopaedia of informal education. Retrieved June 4, 2010, from www.infed.org/biblio/b-curric.htm

Sorensen, E. K., \& Takle, E. S. (2005). Investigating knowledge building dialogues in networked communities of practice. A collaborative learning endeavor across cultures. Interactive Educational Multimedia, 10, 50-60.

Spiro, R. J., Feltovich, P. J., Jacobson, M. J., \& Coulson, R. L. (1992). Cognitive flexibility, constructivism, and hypertext: Random access instruction for advanced knowledge acquisition in ill-structured domains. In T. Duffy \& D. Jonassen (Eds.), Constructivism and the technology of instruction (pp. 57-76). Hillsdale, NJ: Lawrence Erlbaum Assoc.

Squires, D. (1999). Educational software for constructivist learning environments: Subversive use and volatile design. Educational Technology, 39(3), 48-54.

Summers, M., \& Kruger, C. (2003). Teaching sustainable development in primary schools: Theory into practice. The Curriculum Journal, 14(2), 157-180. DOI: 10.1080/0958517032000095763.

Svanstrom, M., Lozano-Garcia, F. J., \& Rowe, D. (2008). Learning outcomes for sustainable development in higher education. International Journal of Sustainability in Higher Education, 19(3), 339-351. DOI: 10.1108/14676370810885925.

Tilbury, D., Podger, D., \& Reid, A. (2004). Action research for change towards sustainability: Change in curricula and graduate skills towards sustainability. Final report prepared for the Australian Government Department of the Environment and Heritage and Macquarie University, September 2004.

UNESCO (United Nations Educational, Scientific and Cultural Organisation). (1996). Learning: The treasure within, report to UNESCO of the international commission on education for the twentieth century. Paris: UNESCO.

UNESCO (United Nations Educational, Scientific and Cultural Organisation). (2003). The Decade of Education for Sustainable Development: Framework for a draft international implementation scheme. Paris: UNESCO. 
UNESCO (United Nations Educational, Scientific and Cultural Organisation). (2005). Guidelines and recommendations for reorienting teacher education to address sustainability, UNESCO education for sustainable development in action. Technical Paper No. 4. Paris: UNESCO.

UNESCO (United Nations Educational, Scientific and Cultural Organisation). (2010). Education for sustainable development lens: A policy and practice review tool. Education for sustainable development in action learning \& training tools. No. 2. Paris: UNESCO.

Vare, P., \& Scott, B. (2007). Learning for a change: Exploring the relationship between education and sustainable development. Bath: Learning South West.

Vrasidas, C. (2001). Constructivism versus objectivism: Implications for interaction, course design, and evaluation in distance education. International Journal of Educational Telecommunications, 6(4), 339-362.

Wade, R. (2012). Pedagogy, places and people. Journal of Teacher Education for Sustainability, $14(2), 147-167$.

Wals, A. E. J. (2007). Introduction. In A. E. J. Wals (Ed.), Social learning towards a sustainable world: Principles, perspectives, and praxis (pp. 17-32). Wageningen: Wageningen Publishers.

Wals, A. E. J., \& Heymann, F. V. (2004). Learning on the edge: Exploring the change potential of conflict in social learning for sustainable living. In A. Wenden (Ed.), Educating for a culture of social and ecological peace (pp. 123-145). Albany, NY: State University of New York Press.

Wals, A. E. J., \& Blaze Corcoran, P. (2006). Sustainability as an outcome of transformative learning. In J. Holmberg \& B. E. Samuelson (Eds.), Drivers and barriers for implementing sustainable development in higher education (pp. 103-108). Paris: UNESCO.

Willis, J. (2000). The maturing of constructivist instructional design: Some basic principles that can guide practice. Educational Technology, 40(1), 5-16.

WCED (World Commission on Environment and Development). (1987). Our common future (Brundtland report). London: Oxford University Press.

Wenger, E., \& Lave, J. (1991). Situated learning: Legitimate peripheral participation. Cambridge: Cambridge University Press.

\section{Correspondence:}

Vassilios Makrakis, Professor of ICT in Education \& UNESCO Chair ICT in Education for Sustainable Development, University of Crete, Department of Primary Education, 74100 Rethymnon, Crete Greece. Email: makrakis@edc.uoc.gr 